Research Article

\title{
Population of Spodoptera exigua Hübner during On- and Off-Season of Shallot in Bantul Regency, Yogyakarta
}

\author{
Fitri Ujiyani $^{1) *}$, Y. Andi Trisyono ${ }^{2)}$, Witjaksono ${ }^{2)}$, \& Suputa ${ }^{2)}$ \\ 1) Agency of Agricultural Quarantine, Ministry of Agriculture Republic of Indonesia \\ Jln. Harsono RM No.3, Gedung E, Lantai 5, Ragunan, Pasar Minggu, South Jakarta 12000 Indonesia \\ ${ }^{2)}$ Department of Plant Protection, Faculty of Agriculture, Universitas Gadjah Mada \\ Jln. Flora No. 1 Bulaksumur, Sleman, Yogyakarta 55281 Indonesia \\ *Corresponding author.E-mail: fitriuji@yahoo.co.id
}

Received July 5, 2018; revised January 22, 2019; accepted March 27, 2019

\begin{abstract}
Beet armyworm (Spodoptera exigua Hübner) (Lepidoptera: Noctuidae) is known to be a polyphagous insect that infests many crops such as welsh onion, maize, tobacco, cotton, and others. In Indonesia, this species is a major pest of shallot. The study was aimed to monitor the population of beet armyworm in the shallot plantation in Bantul District, Yogyakarta. The monitoring was conducted using pheromone traps containing Z-9-tetra decanol $10 \mu \mathrm{g} / \mathrm{rubber}$ unit and Z-9-tetradecadienyl $90 \mu \mathrm{g} /$ rubber unit. The pheromone was placed in the fields to trap males during on- and offshallot plant season. The sites for placing the pheromone traps were selected in the farms where shallot was planted once and twice per year. The selected sites were with shallot and non-shallot in their surrounding areas. The result showed that males emerged both on-and off-shallot planting seasons in most of the areas. The average number of trapped males during the shallot season was $<5$ males/trap/week. The number increased and reached the peak $(7.33$ males/trap/week) in June until July which was the off-shallot season. The population reduced to $<2 \mathrm{males} / \mathrm{trap} / \mathrm{week}$ at the end of the second shallot planting season until the end of the year where the fields were mostly planted with rice. These findings indicate that the beet armyworm presents all year around with or without shallot in the fields. It suggests that the management of this insect should be done not only during the shallot season but also during the remaining seasons to obtain more effectiveness.
\end{abstract}

Keywords: Spodoptera exigua, shallot, trapping

\section{INTRODUCTION}

Spodoptera exigua (Hübner) (Lepidoptera: Noctuidae) is a polyphagous insect that infests various types of vegetables, field, and ornamental plants (Amaldos \& Hsue, 1989; Capinera, 2017). S. exigua is reported to be a major pest of welsh onion in Vietnam, onion and tobacco in India; cotton in Egypt; and maize in Turkey (Amaldos \& Hsue, 1989; Sertkaya et al., 2004; Ueno, 2015; Arulkumar et al., 2017). In Indonesia, S. exigua infests many shallot varieties hence it is known as the beet armyworm (Rauf, 1999). $S$. exigua is being a problem in the shallot plantations in Indonesia, including in Brebes and Cirebon (Basuki, 2009). S. exigua were from Southeast Asia (Amaldos \& Hsue, 1989; Capinera, 2017) and has been widely spread to several countries in Asia, Africa, North America, Central America, and the Caribbean, from Europe to Oceania (CABI, 2019). The damage in the plant was caused by larval feeding activity on the leaves and fruits (Capinera, 2017).
The control techniques are carried out to reduce the impact of $S$. exigua on various crops. One of the control techniques used by farmers is conventional insecticides, such as spinosad, chlorpyrifos, triazophos, methomyl, beta-cyfluthrin, cyromazine, carbosulfan, thiodicarb, and abamectin which are commonly used by farmers in Cirebon, Brebes, and Tegal that lead to the pest resistance (Moekasan \& Basuki, 2007). Resistance to metoxifenocide, an agonist ecdysone on $S$. exigua, has been reported in the central production of shallot in Java (Wibisono et al., 2007). S. exigua were also resistant to indoxacarb, spinosad, and emamectin benzoate (Ahmad et al., 2018). Besides resistance, the use of insecticides can harm the farmer. As reported by Kishi (1995), farmers in Indonesia are at risk of acute pesticide poisoning which exposure when spraying their plants. This risk can be avoided by reducing the frequency of the use of insecticides. 
Population monitoring can be used as an effort to reduce insecticides application. In the field, pest population fluctuates (Wallner, 1987; Untung, 1996) thus monitoring population density is important to be conducted. One method for monitoring the existence and density of population is pheromone trap (Carde, 1976; Roelofs, 1980). Pheromones are chemical substances released by insects to influence the behavior or communicate with other insects in one species, for example to mate (Marx, 1973; Silverstein, 1981; Mitchell, 1986; Yew \& Chung, 2015). Pheromone traps are used to attract male insects into the trap to prevent them from finding females to mate (Mitchell, 1975). Through monitoring the existence and density of populations with pheromone traps, the control using pesticides could be decided (Roelofs, 1980; Mitchell, 1975), for example when the pests are found or when the population reaches the economic threshold (Marx, 1973; Carde, 1976).

Pheromones can also be used as mass traps of adult insects to reduce the population (Marx, 1973; Mitchell, 1986). Pheromone traps can detect and monitor insect activity and estimate population density (Majumdar \& Reed, 2013; Roelofs, 1980). However, the number of insects trapped in pheromone traps need to be interpreted in advance because the number of trapped insects does not show the proportion of insects in the field (Roelofs, 1980; Silverstein 1981). This study was aimed to monitor the population dynamics of $S$. exigua in shallot in Bantul Regency, Yogyakarta, which is one of the shallot production areas in Indonesia hence the results of this monitoring can be used as a consideration in determining the appropriate control technique. Monitoring was performed using pheromone traps and focused on the trapped males of $S$. exigua during on- and off-shallot plant season.

\section{MATERIALS AND METHODS}

\section{Preparation of Pheromone Traps}

Pheromone traps used in this study contain the active ingredient of Z-9-tetra decanol $10 \mu \mathrm{g} /$ rubber and Z-9-tetra decadent $90 \mu \mathrm{g} /$ rubber (Feromon Exi ${ }^{\circledR}$, CV. Nusagri, Bogor) registered in the Ministry of Agriculture, Republic of Indonesia (Kementerian Pertanian, 2014) and are commercially available. Pheromones in the form of small rubber cylinders were hung on the inside of the lid of a plastic container $(11 \mathrm{~cm}$ in diameter and $21 \mathrm{~cm}$ in high). The container was equipped with openings on both sides facing each other $(12 \mathrm{~cm}$ in length and $3 \mathrm{~cm}$ in width). The container was then filled with water, approximately $5 \mathrm{~cm}$ from the bottom. The attracted males would enter the container through both openings and be trapped into the water at the bottom of the container (Figure 1). A series of pheromone traps were hung on bamboo sticks and placed on a shallot plantation $(15 \mathrm{~cm}$ from the leaf surface or 40 $\mathrm{cm}$ from the ground surface).

\section{Pheromone Traps Installation}

Ten shallot plantations were selected as monitoring areas with each area varying between 500-2000 $\mathrm{m}^{2}$ (Table 1), in Bantul District: Sanden, Kretek, and Srandakan Regencies (Figure 2). This area was chosen to represent the central production area of shallots. In each field, three pheromone traps were randomly placed as replications. The number of pheromone traps placed in each area based on the dosage recommendation. The dosage recommendation of Feromon Exi ${ }^{\circledR}$ on shallots is 5 traps/ha (Moekasan

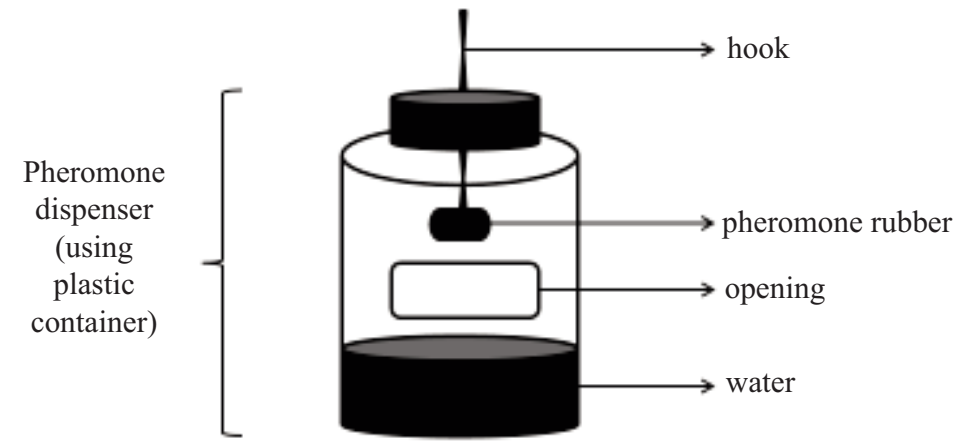

Figure 1. The structure of pheromone traps of Spodoptera exigua (Hübner); the pheromone rubber were hung in a windowed plastic container with water at the bottom 
et al., 2013). The rubber pheromones were replaced at $8^{\text {th }}$ weeks since the first installation and continued every 5 weeks to avoid the less effectiveness of pheromones by evaporation in the field.
The number of trapped males was observed and calculated once a week. The monitoring was conducted in early April to late November 2016 that includes two shallot seasons and two non-shallot seasons (34 weeks).

Tabel 1. Distribution of the pheromone traps of Spodoptera exigua (Hübner) on shallot plantations in the Regencies of Srandakan, Sanden and Kretek, District of Bantul, the Special Region of Yogyakarta

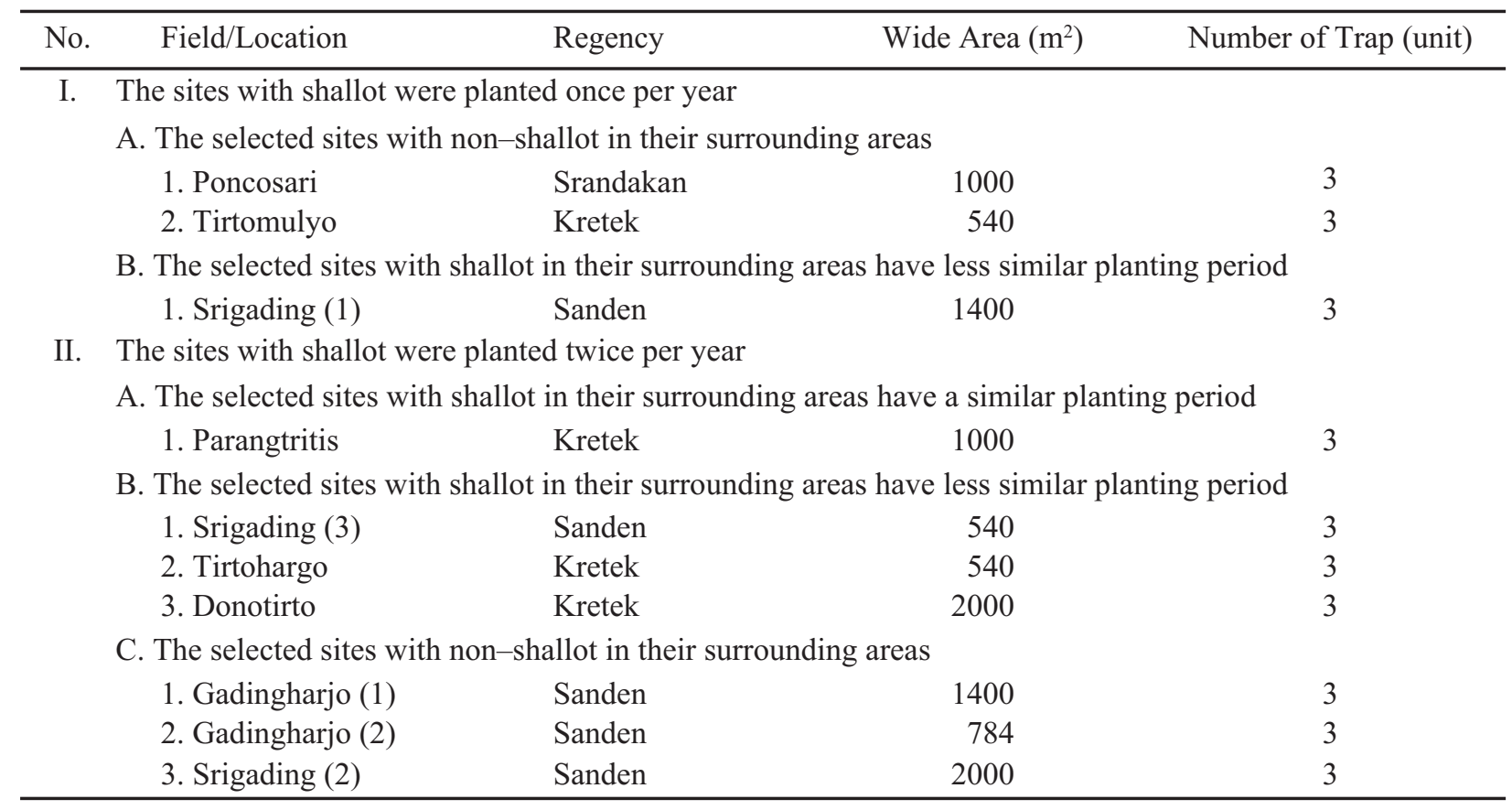

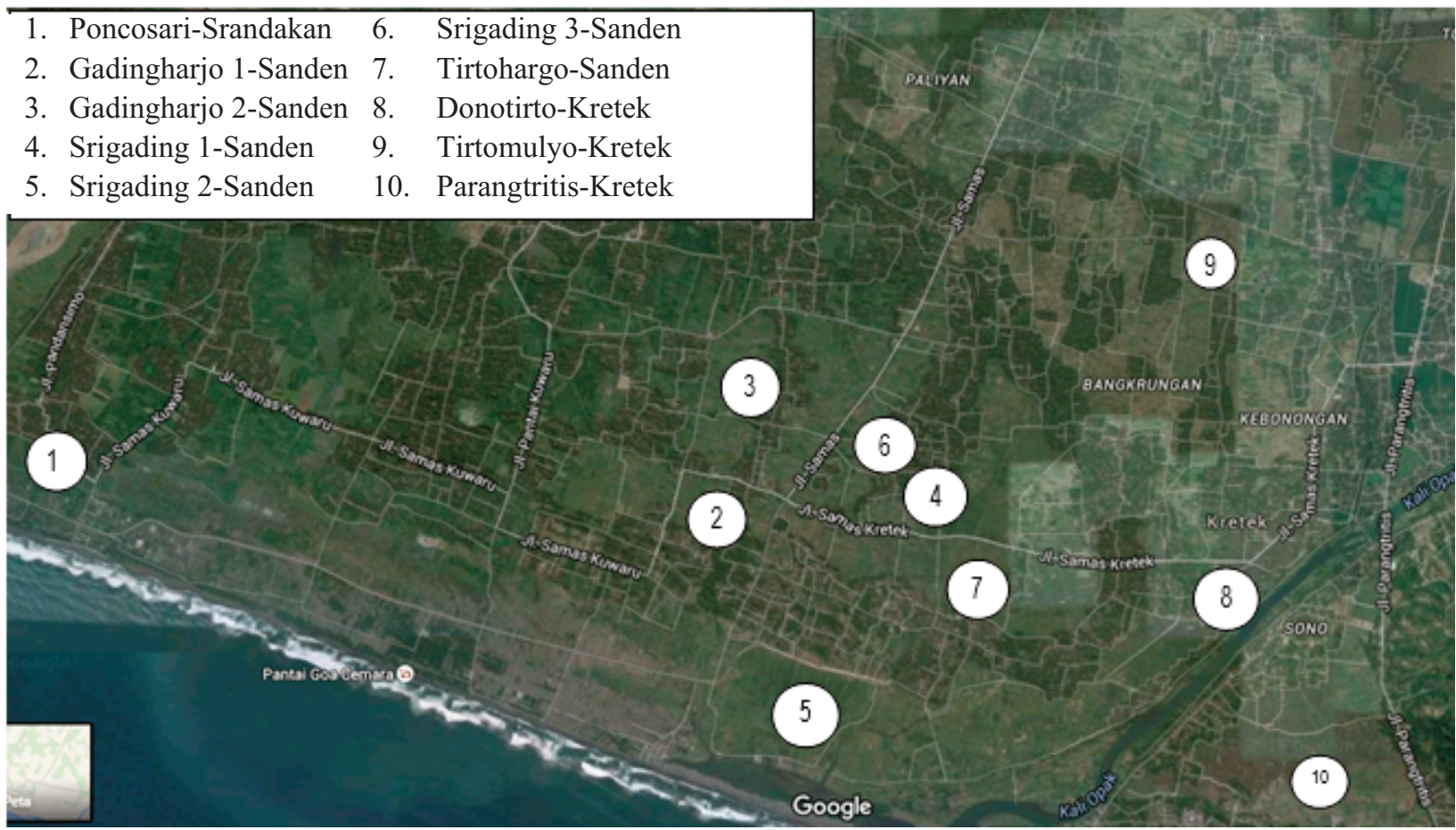

Figure 2. Map location of the pheromone traps installation to monitor the population of Spodoptera exigua (Hübner) in the shallot plantation in Bantul, Yogyakarta; three pheromone traps were placed in each location 
Each shallot season lasted approximately two months. Generally, the first shallot season started at the beginning of April until the end of May, while the second planting season began in late July to late September.

\section{Grouping Location Based on the Shallot Planting Season}

The cropping patterns applied in each monitoring and the surrounding field are different. The period of the on- and off-shallot planting season both in the monitoring and the surrounding field within a radius of $1 \mathrm{~km}$ was recorded. Each area has different cropping patterns, both in terms of the time of planting or the type of plant cultivated. Monitoring fields that have similar conditions to the field in other areas were grouped according to the cropping pattern and the diversity of the surrounding plants. The ten sites were grouped into five categories: 1) area with once shallot planting season per year and their surrounding area was non-shallot vegetation (Poncosari-Srandakan and Tirtomulyo-Kretek); 2) area with once shallot planting season per year and their surrounding area has a less similar shallot planting period (Srigading 1-Sanden);
3) area with twice shallot planting season per year and their surrounding area has a similar shallot planting period (Parangtritis-Kretek); 4) area with twice shallot planting season per year and their surrounding area has a less similar shallot planting period (Srigading 3-Sanden, Tirtohargo-Kretek, and Donotirto-Kretek); and 5) area with twice shallot planting per year and the surrounding area was nonshallot vegetation (Srigading 2-Sanden, Gadingharjo 1Sanden, and Gadingharjo 2-Sanden).

Figure 3 showed that the first shallot planting season lasted from early April to early June. After that, the field was off-shallot planting season lasted until mid-July. During this period, the farmers generally planted chili that has ben previously planted together with shallots or other seasonal crops, such as eggplant, choy sum, spinach, and other plants. The second shallot planting season in most of the areas was started in mid-July and ended at the end of September. After the end of the shallot planting season, the field was planted with rice that lasted for three months until the end of the year or the period of planting shallots the following year.

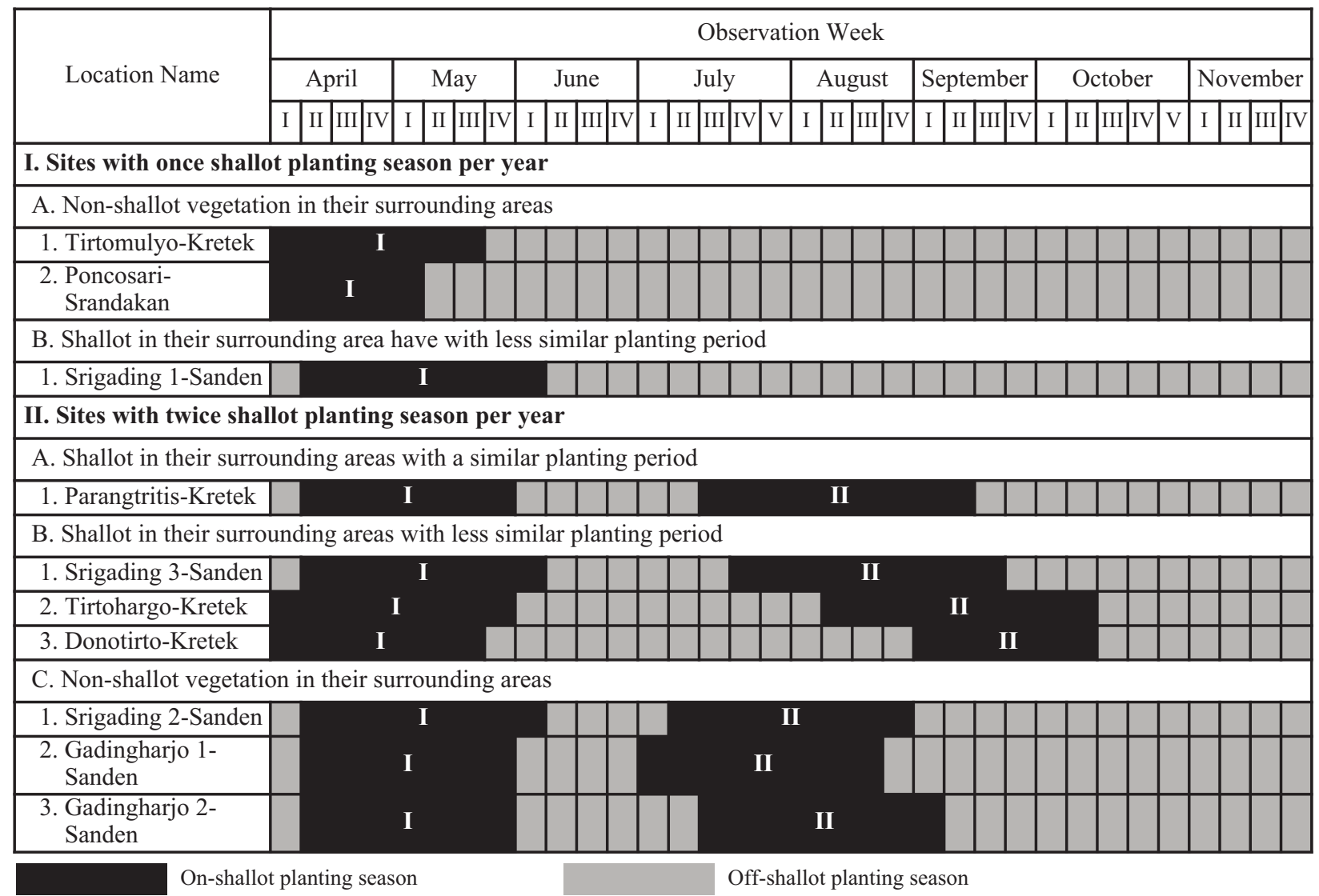

Figure 3. An illustration of the cropping pattern of the on- and off-shallot planting in each field observations in Bantul Regency, Yogyakarta in 2016 


\section{Data Analysis}

The trapped males from ten sites were grouped by category. The average number of trapped males in each category was calculated.

\section{RESULTS AND DISCUSSION}

\section{Shallot was Planted Once per Year with Non-Shallot in their Surrounding Areas}

The trapped males were found all the time in this area. The trapped males in April-May-June were higher than in other months (Figure 4). The highest average number of trapped males was in May and June (2.83 males/week). April-May was the shallot planting period in the monitoring area. The trapped males were still present when shallot was no longer available in the field, from June to October in the low amount $(<1.33 \mathrm{male} / \mathrm{trap} / \mathrm{week})$. In that period, the monitoring area was planted with chili and then rice until the end of the year. The surrounding areas were planted with various types of commodities such as rice, peanut, melon, watermelon, chili, spinach, corn, and sugar cane.

A. Their surrounding area was non-shallot vegetation

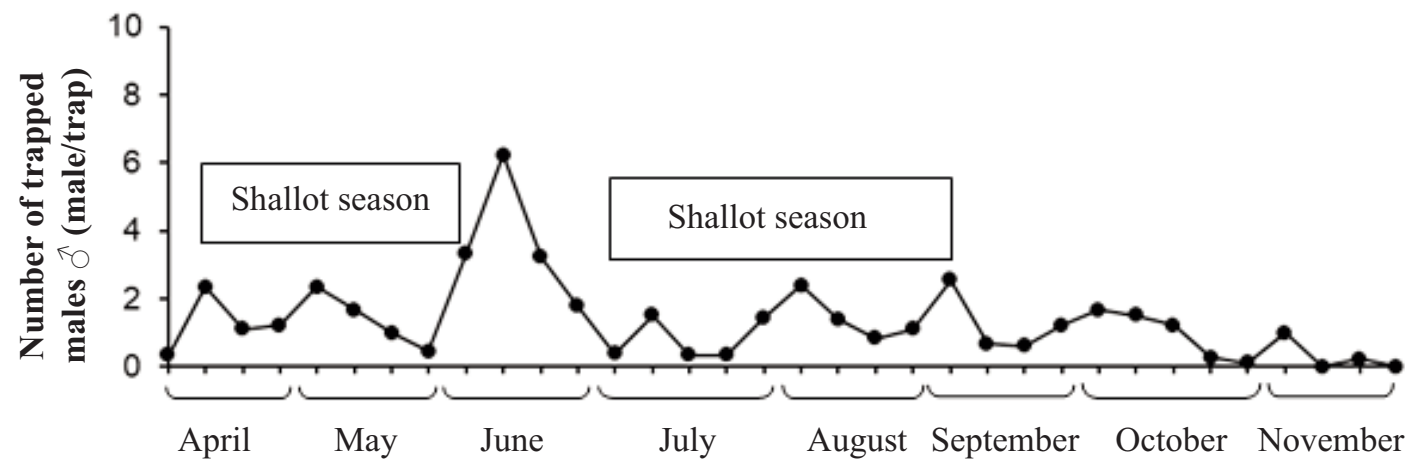

B. Their surrounding area has a less similar shallot planting period

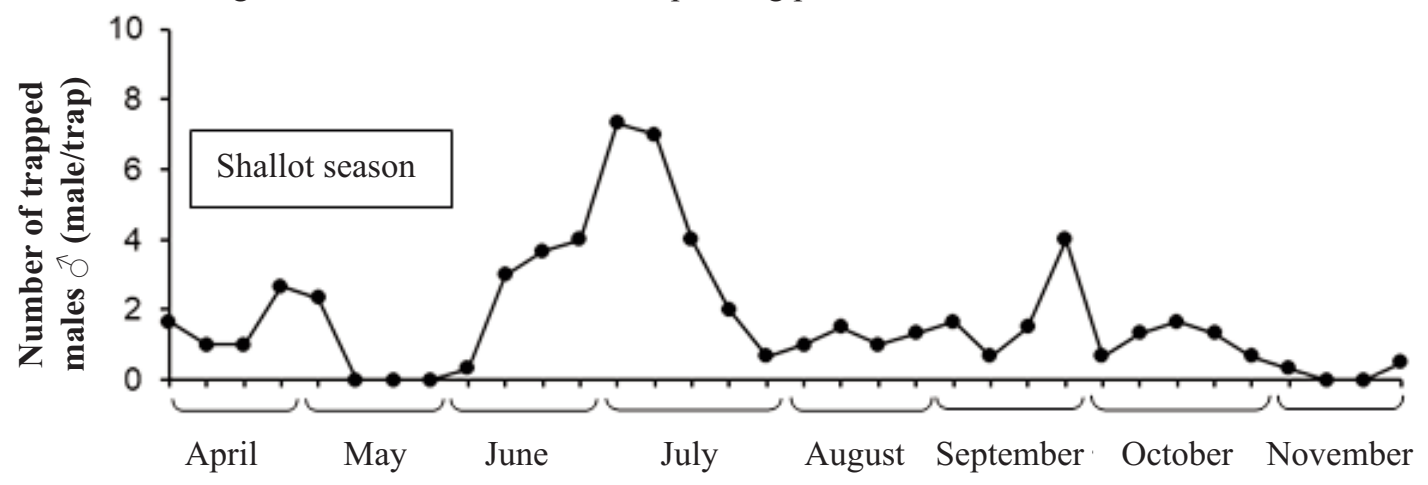

Figure 4. The average fluctuations of trapped males of Spodoptera exigua (Hübner) per trap per week from April to November 2016 on the selected sites with once shallot planting season per year. The surrounding area of trapping sites were planted with non-shallot vegetation (A) and planted with shallot with a less similar planting period (B) 
A. The surrounding area has a similar shallot planting period

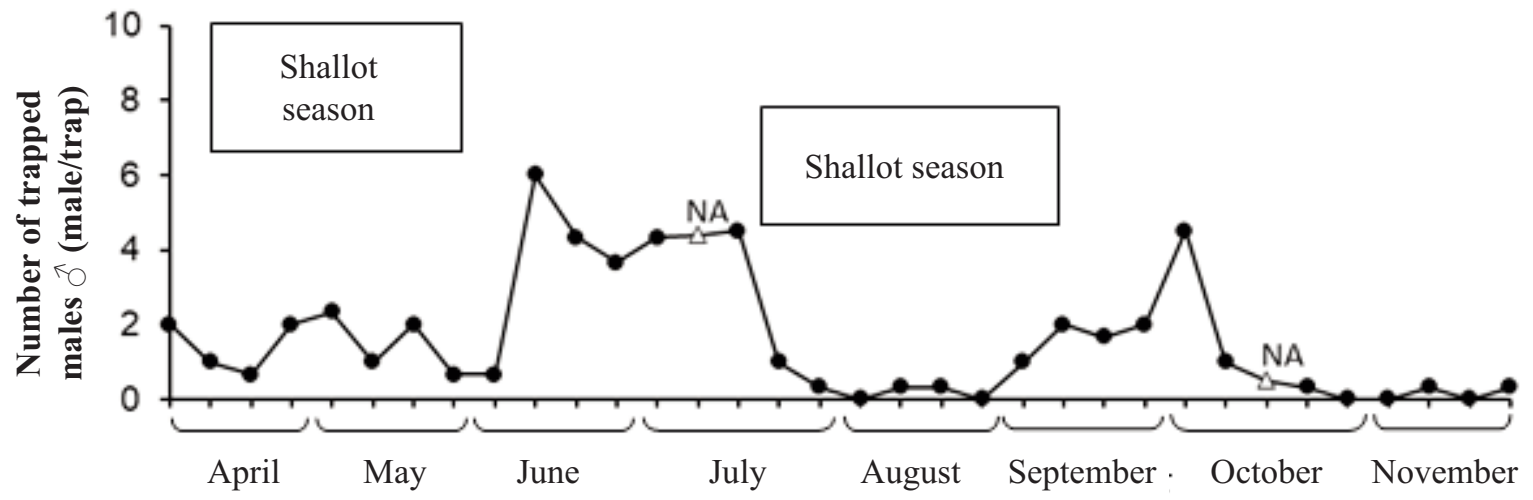

B. The surrounding area has a less similar shallot planting period

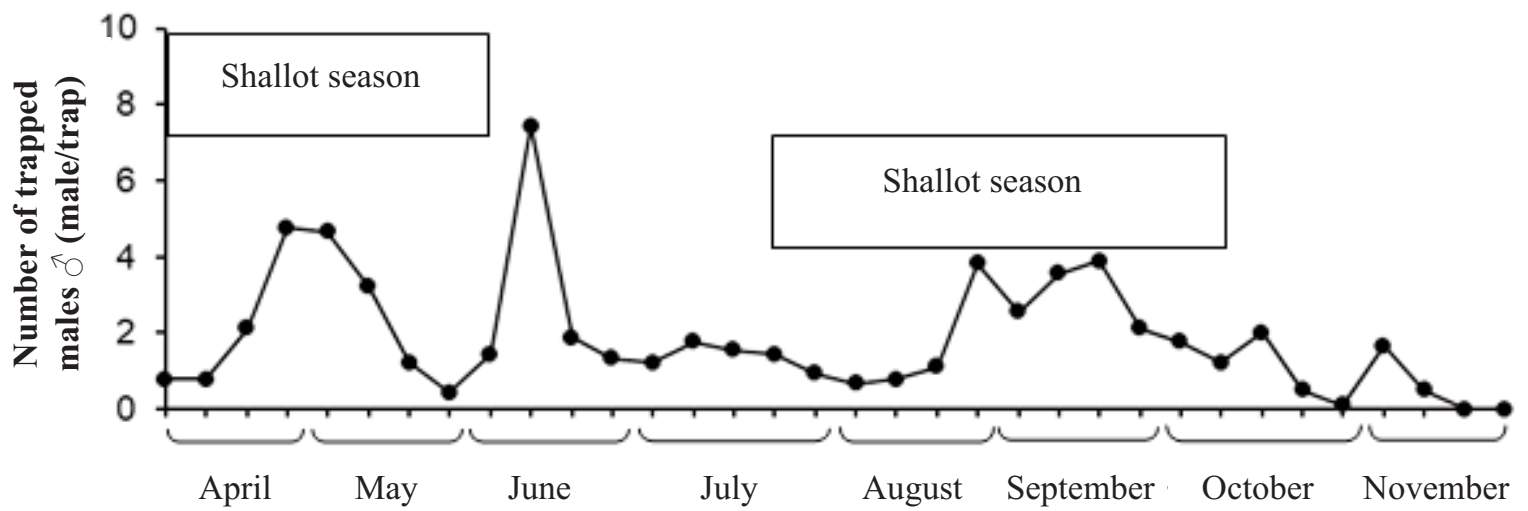

C. The surrounding area was non-shallot vegetation

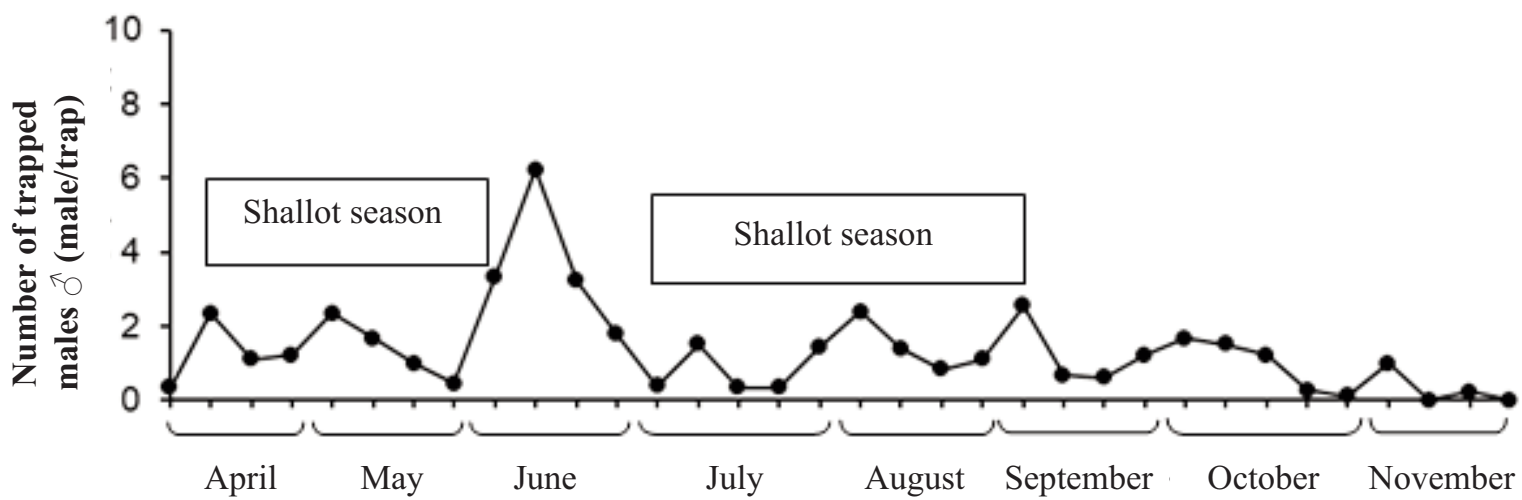

Figure 5. The average fluctuations of trapped males of Spodoptera exigua (Hübner) per trap per week (April to November 2016) on the selected sites with twice shallot planting seasons per year. The surrounding area of trapping sites were planted with shallot with a similar planting period (A), planted with shallot with less similar planting period (B) and planted with non-shallot vegetation (C).

in the first off-shallot planting season (mid-June to July), the trapped males increased more than in April and May (the on-shallot planting season). The number of trapped males in the second shallot planting season decreased $(<5$ males/trap/week), but was higher than in the first planting season. The trapped males were low $(<1$ male/trap/week) at the end of the second shallot planting season where the fields were mostly planted with rice.

\section{Shallot was Planted Twice per Year with Shallot in their Surrounding Areas Has Less Similar Planting Period}

The males were trapped throughout the year in this category areas, both on- and off-shallot planting season (Figure 5). The average number of trapped males in the first shallot planting season was higher (4.78 males/trap/week early, in April to early June) than in the second shallot planting season (3.89 males/ 
trap/week, in late July to mid-October). The number of trapped males increased at the end of the first shallot planting season (around mid-June) (7.44 males/trap/week). During the off-shallot planting season, the males were also trapped until the second shallot planting season. This number of trapped males decreased $(<2$ males/trap/week) at the end of the year where the fields were mostly planted with rice.

\section{Shallot was Planted Twice per Year with Non-Shallot in their Surrounding Areas}

In this category, the males were trapped both during the on- and off-shallot planting season. The monitoring showed that the average number of trapped males in both shallot season was quite low ( $<3 \mathrm{males} /$ trap/week) (Figure 5). The highest number of trapped males was at the beginning of June or at the end of the first planting season (6.22 males/ trap/week). The total number of trapped males at the end of the second shallot planting season until the end of the year was quite low ( $<1 \mathrm{male} / \mathrm{trap} /$ week).

The males emerged all the time in 2016, both on the selected sites with once and twice shallot seasons per year with shallot or non-shallot in their surrounding areas. The highest number of trapped males was in June-July in most the areas, although that period has entered off-shallot planting season. This might be caused by a less similar planting period hence although most of the areas were off-shallot planting season, the shallot were still available around the areas. In the period between the first and second shallot planting season, farmers generally planted various types of plants, i.e. chili, eggplant, peanut, spinach, and choy sum which provide the alternative hosts for S. exigua (Amaldos \& Hsue, 1989; Capinera, 2017). When the availability of the main host decreases, $S$. exigua can migrate to their alternative host. Moreover, the high trapped males of $S$. exigua in that period might be relevant to the dry season in June. Rauf (1999) reported that in the dry season there was an outbreak of S. exigua.

The relationship between the availability of shallot with the number of trapped males $S$. exigua was showed in the comparison of trapped males in the on-and off-shallot planting season. The number of trapped males with non-shallot in their surrounding areas (Figure 4A) has a trend to be lower than the selected sites with shallot in their surrounding areas
(Figure 4B). This result was similar to Khaliq et al. (2014) that insect population fluctuations are influenced by the diversity of vegetation in the surrounding areas. The lowest number of trapped males was where shallot planted once per year with non-shallot in their surrounding areas (Figure 4A). The decline in the number of trapped males was at the end of the year after the end of the second shallot planting season. At that time, most of the areas were off-shallot planting season, resulting in a lack of food availability for S. exigua. The cropping pattern at the end of the year is different from the cropping pattern during the off-shallot planting season (June-July) where farmers planted various types of plants. At the end of the year, most of the areas was only planted with rice. Changes in plant diversity would influence pest migration (Khaliq et al., 2014). Pests most likely move to other areas that are more suitable for their development because they are also able to move into distant areas, both across the ocean and terrestrial (Mikkola, 1970; Carde, 2008). Another factor affecting the low number of trapped males at this period is that the rainy season at the end of the year which can affect the changes in the insect population (Stiling, 1988). The previous study also reported a similar result that the larval populations found in the rainy season were much lower than in the dry season (Rauf, 1999).

The results of this study showed that $S$. exigua was present all year around, both during the on- and off-shallot planting season despite fluctuations during the monitoring period. These findings were considered to influence the decision to obtain more effective management strategies. For example, the control management of $S$. exigua is not only conducted during the shallot season but also before the onshallot planting season to prevent the outbreak of $S$. exigua. Conventional insecticides could be done based on monitoring the number of trapped males beyond the economic threshold. Moekasan et al. (2013) reported that the economic threshold of $S$. exigua is $10 \mathrm{males} / \mathrm{trap} /$ day with the dosage of pheromone was 5 traps/ha. By implementing an appropriate management strategy based on the findings of this study, the resources cost by farmers to control S. exigua and yield losses caused by $S$. exigua can be reduced. 


\section{CONCLUSION}

S. exigua males were found all year around, both on- and off-shallot planting season. The average number of trapped males in most of the areas during the shallot planting season was $<3$ males/trap/week. The number of trapped males increased and reached the peak (7.44 males/trap/week) at the end of the first planting season to begin the off-shallot planting season. The lowest number of trapped males was found at the second shallot planting season ended when the fields were mostly planted with rice. However, during this period, the males were still trapped in several areas even in a small amount ( $<2$ males/trap/week).

\section{ACKNOWLEDGEMENTS}

The authors thank the Ministry of Agriculture of the Republic of Indonesia and the Local Government of Bantul District, the Special Region of Yogyakarta, for allowing the authors to complete this research; and the farmers in Sanden, Kretek, and Srandakan Regencies for assisting the authors during the research. This paper is part of a dissertation entitled "The Role of Biotic Factors in Regulating the Population Dynamics of Spodoptera exigua (Hübner)".

\section{LITERATURE CITED}

Ahmad, M., A. Farid, \& M. Saeed. 2018. Resistance to New Insecticides and Their Synergism in Spodoptera exigua (Lepidoptera: Noctuidae) from Pakistan. Crop Protection 107: 79-86.

Amaldos G. \& N.C. Hsue. 1989. The Biology and the Reproductive Morphology of Beet Army Worm Spodoptera exigua (Hübner) (Lepidoptera: Noctuidae). Chinese Journal of Entomology 9: 239-250.

Arulkumar, G., S. Manisegaran, R. Nalini, \& M. Mathialagan. 2017. Seasonable Abundance of Beet Armyworm Spodoptera exigua (Hübner) Infesting Onion with Weather Factors in Madurai District of Tamil Nadu. Journal of Entomology and Zoology Studies 5: 1157-1162.

Basuki, R.S. 2009. Pengetahuan Petani dan Keefektifan Penggunaan Insektisida oleh Petani dalam Pengendalian Ulat Spodoptera exigua Hübn. pada Tanaman Bawang Merah di Brebes dan Cirebon. Jurnal Hortikultura 19: 459-474.

Capinera, J. L. 2017. Beet Armyworm, Spodoptera exigua (Hübner) (Insecta: Lepidoptera: Noctuidae). UF/IFAS Extension. 4 p.
Carde, R.T. 1976. Utilization of Pheromones in the Population Management of Moth Pests. Environmental Health Perspectives 14: 133-144.

Carde, R.T. 2008. Insect Migration: Do Migrant Moths Know Where They are Heading? Current Biology 18: 472-474.

CABI. 2019. Spodoptera exigua (Beet Armyworm) Datasheet. Crop Protection Compendium. https://www.cabi.org/cpc/datasheet/29808, modified 22/01/2019.

Kementerian Pertanian. 2014. Pestisida Pertanian dan Kehutanan Terdaftar. Direktorat Jenderal Prasarana dan Sarana Pertanian. Kementerian Pertanian, Jakarta. 822 p.

Khaliq, A., M. Javed, M. Sohail, \& M. Sagheer. 2014. Environmental Effects on Insects and their Population Dynamics. Journal of Entomology and Zoology Studies 2: 1-7.

Kishi, M., N. Hirschhorn, M. Djajadisastra, L.N. Satterlee, S. Strowman, \& R. Dilts. 1995. Relationship of Pesticide Spraying to Signs and Symptoms in Indonesian Farmers. Scandinavian Journal of Work, Environment \& Health 21: 124-133.

Majumdar, A. \& T. Reed. 2013. Pheromone Traps for Monitoring Insect Pests. Alabama Cooperative Extension System. www.aces.edu, modified 25/10/2016. 4 p.

Marx, J.L. 1973. Insect Control (I): Use of Pheromones. Science 1801: 736-737.

Mikkola, K. 1970. The Interpretation of LongRange Migrations of Spodoptera exigua $\mathrm{Hb}$. (Lepidoptera: Noctuidae). Journal of Animal Ecology 39: 593-598.

Mitchell, E.R. 1975. Disruption of Pheromonal Communication among Coexistent Pest Insect with Multichemical Formulations. BioScience 25: 493-499.

Mitchell, E.R. 1986. Pheromones: As the Glamour and Glitter Fade: The Real Work Begins. The Florida Entomologist 69: 132-139.

Moekasan, T.K. \& R.S. Basuki. 2007. Status Resistensi Spodoptera exigua Hübn. pada Tanaman Bawang Merah Asal Kabupaten Cirebon, Brebes, dan Tegal terhadap Insektisida yang Umum Digunakan Petani di Daerah Tersebut. Jurnal Hortikultura 17: 343-354.

Moekasan, T.K., W. Setiawati, F. Hasan, R. Runa, \& A. Somantri. 2013. Penetapan Ambang Pengendalian Spodoptera exigua pada Tanaman Bawang Merah Menggunakan Feromonoid Seks. Jurnal Hortikultura 23: 80-90. 
Rauf, A. 1999. Dinamika Populasi Spodoptera exigua (Hübner) (Lepidoptera: Noctuidae) pada Pertanaman Bawang Merah di Dataran Rendah. Bulletin of Plant Pests and Diseases 11: 39-47.

Roelofs, W.L. 1980. Developing the Potential of Lepidopterous Pheromones in Insect Control of Pest Organisms. Ecological Bulletins 31: 25-40.

Sertkaya, E., A. Bayram, \& S. Kornosor. 2004. Egg and Larval Parasitoids of the Beet Armyworm Spodoptera exigua on Maize in Turkey. Phytoparasitica 32: 305-312.

Silverstein, R. M. 1981. Pheromones: Background and Potential for Use in Insect Pest Control. Science, New Series 213: 1326-1332.

Stiling, P. 1988. Density-Dependent Processes and Key Factors in Insect Population. Journal of Animal Ecology 57: 581-593.
Ueno, T. 2015. Beet Armyworm Spodoptera exigua (Lepidoptera: Noctuidae): a Major Pest of Welsh Onion in Vietnam. Journal of Agriculture and Environmental Sciences 4: 181-185.

Untung, K. 1996. Pengantar Pengelolaan Hama Terpadu. Gadjah Mada University Press. Yogyakarta. $273 \mathrm{p}$.

Wallner, W.E. 1987. Factors Affecting Insect Population Dynamics: Differences between Outbreak and Non-Outbreak Species. Annual Review of Entomology 32: 317-40.

Wibisono, I, I., Y.A. Trisyono, E. Martono, \& A. Purwantoro. 2007. Evaluasi Resistensi terhadap Metoksifenozida pada Spodoptera exigua di Jawa. Jurnal Perlindungan Tanaman Indonesia 13: 127-135.

Yew, J. Y., H. Chung. 2015. Insect Pheromones: An Overview of Function, Form, and Discovery. Progress in Lipid Research 59: 88-105. 